\title{
Penerapan K-Nearest Neighbor dalam Pendeteksian Abcessus
}

\author{
Puji Sari Ramadhan \\ STMIK TRIGUNA DHARMA, Jl. AH Nasution, 20144, Medan, Indonesia
}

\section{KEYWORDS}

Kecerdasan Buatan, Sistem Pakar, K-Nearest

Neighhbor, Abcessus

\section{CORRESPONDENCE}

Phone: +6287868974046

E-mail: pujisariramadhan@gmail.com

\section{PENDAHULUAN}

Seperti diketahui bahwa Abcessus merupakan penyakit yang menyerang jaringan kulit dengan penyebaran toksin atau racun yang dihasilkan oleh bakteri staphylococcus aureus. Akibat dari penyebaran toksin yang dilakukan oleh staphylococcus aureus adalah terjadinya peradangan pada sel kulit serta meningkatnya aliran darah menuju sel yang telah terinfeksi, hal ini akan memberikan respon sel darah putih untuk mengantisipasi toksin yang ada pada sel, hal tersebut menyebabkan timbulnya pembengkakan dan keluarnya nanah pada sel atau jaringan kulit tersebut.

Penyakit ini dikategorikan sebagai penyakit yang tidak menular, namun tetap saja masyarakat tetap mengantisipasi penyebaran penyakit ini, hal ini dikarenakan bahwa masyarakat memiliki kemungkinan terjangkit oleh bakteri staphylococcus aureus, maka hal tersebut perlu diantisipasi dengan cara membangun sebuah sistem yang mampu memberikan pengetahuan dan informasi yang berkaitan dengan Abcessus, sehingga nantinya masyarakat dapat mengetahui tentang pendiagnosaan Abcessus yang tentunya dapat mempercepat penanganan dini terhadap masyarakat yang terkena Abcessus.

Sistem yang akan dibangun untuk pendiagnosaan Abcessus adalah dengan menghasilkan layanan konsultasi berbentuk aplikasi yang didalamnya terdapat informasi dan pengetahuan tentang Abcessus yang diperoleh dari keilmuan pakar atau ahli dalam penyakit Abcessus. Sistem ini akan bekerja dengan

\begin{abstract}
A B S T R A A C T
Abcessus is a collection of neutrophils that do not function anymore and have accumulated in cavities infected with bacteria or parasites. This disease will cause swelling in the part forms of information and knowledge about Abcessus into the diagnosing application by diagnostic applications this can be used as a source to be used by the wider community in dealing with problems regarding diagnosis and knowledge of Abcessus, besides that it can
\end{abstract}

menyesuaikan penggunaan konsep Sistem Pakar menggunakan analisis K-Nearest Neighbor yang memiliki fungsi untuk menghasilkan diagnosa dengan memperhatikan nilai kondisi pada kasus sebelumnya, hal ini bertujuan untuk mendapatkan hasil pendiagnosaan yang lebih akurat dan baik.

Penggunaan Sistem Pakar ternyata telah banyak diimplementasikan pada kehidupan sehari-hari dalam menemukan suatu tujuan atas kasus yang terjadi dilingkungan masyarakat dengan diawali proses penanaman pengetahuan ahli ke dalam layanan aplikasi atau sistem, hal ini dapat terlihat dari banyaknya jurnal atau karya ilmiah yang menerapkan konsep Sistem Pakar salah satu diantaranya adalah dalam dunia kesehatan sebut saja pada[1] digunakannya Sistem Pakar dalam pendiagnosaan terhadap penyakit kulit pada kucing, selanjutnya dalam[2] Sistem Pakar diimplementasikan untuk mengetahui diagnosa kanker reproduksi, selain itu terdapat juga [3] yang menyebutkan bahwa Sistem Pakar mampu melakukan pendiagnosaan terhadap penyakit Dermatitis Imun.

Disamping itu pula dalam[4] dipergunakannya Sistem Pakar untuk melakukan pendeteksian terhadap penyakit Varicella, kemudian pada[5] mengemukakan bahwa penggunaan Sistem Pakar juga dimanfaatkan dalam pengidentifikasian penyakit gigi dan mulut, selain itu terdapat dalam[6] yang mengutarakan bahwa Sistem Pakar telah mampu berkontribusi dalam memprediksi pasien demam berdarah disebuah rumah sakit, tidak hanya itu penggunaan Sistem Pakar juga diterapkan pada[7] untuk pendiagnosaan Polymaglia Rematik serta dalam[8] digunakannya Sistem Pakar untuk mendeteksi penyakit Tuberkolosis.

Attribution-NonCommercial 4.0 International. Some rights reserved 
Selain dunia medis, pengeimplementasian Sistem Pakar juga sering diterapkan dalam aktifitas lainnya seperti pada[9] penggunaan Sistem Pakar dibidang tanaman dengan mengidentifikasi penyakit dan hama ubi, selain itu Sistem Pakar juga diterapkan pada[10] dalam pendiagnosaan bandeng berformalin, kemudia penggunaan Sistem Pakar dibidang perangkat teknologi juga pernah digunakan dalam[11] pendeteksian kerusakan jaringan dan [12] gangguan smartphone. Selain penggunaan Sistem Pakar, terdapat penerapan metode K-Nearest Neighbor yang telah digunakan pada berbagai permasalahan seperti pada[13] menjelaskan penggunaan $K$-Nearest Neighbor dalam menganilisis penyakit kanker serta digunakannya dalam mengidentifikasi kemiripan pola wajah[14].

Dengan hadirnya aplikasi diagnosa ini diharapkan nantinya dapat berguna untuk masyarakat umumnya dalam mengetahui hal-hal yang berkaitan dengan pendiagnosaan Abcessussehingga mampu menekan angka pertumbuhan dan penularan penyakit serta mempercepat penanggulangan medis secara dini, disamping itu juga nantinya dapat dipergunakan sebagai langkah antisipasi pencegahan terhadap penyakit Abcessus.

\section{METODE PENELITIAN}

\section{Kecerdasan Buatan}

Terdapat pendapat dalam[15] bahwa kecerdasan buatan dapat diartikan sebagai alat yang digunakan untuk mengelola faktafakta serta analisa yang nantinya dapat dihasilkan menjadi sebuah solusi yang bermanfaat bagi manusia, selain itu kecerdasan buatan didefinisikan dalam[16] sebuah sistem yang terdapat didalamnya filosifi analisis dan konsep matematika yang diketemukan oleh Goorge Boole digunakan untuk menyelesaikan permasalahan seperti manusia lakukan.

\section{Sistem Pakar}

Disebutkan bahwa Sistem Pakar merupakan layanan penyedia informasi dan pengetahuan tentang beberapa hal yang sebelumnya telah dimasukkan basis pengetahuan yang bertujuan untuk memecahakan permasalahan yang ada[17], selain itu terdapat pendapat lainnya [18] mengemukakan bahwa Sistem Pakar memiliki definisi sebuah metode yang berasal dari kecerdasan buatan yang tujuannya untuk menemukan kesalahankesalahan yang dilakukan sistem, sehingga hasil dari penemuan kesalahan tersebut adalah berupa solusi atau penyelesaian permasalahan.

Disamping itu juga definisi Sistem Pakar terdapat pada[19] yang menyebutkan bahwa sebuah yang memiliki kecerdasan dalam menemukan solusi atas permasalahan yang terjadi dan dapat dikatakan sebagai pengambil keputusan terbaik, serta pada [20] disampaikan bahwa keberadaan Sistem Pakar telah lama dipergunakan dalam mendukung pengambilan kesimpulan, hal ini terlihat dengan penggunaan MYCIN dalam dunia kesehatan yang muncul pada pertengahan 1960. Sistem Pakar juga dapat diartikan sebagai alat yang mengacu pada pengetahuan yang diambil dari kepakaran yang digunakan untuk pedoman dalam menyelesaikan permasalahan yang terjadi[21].

Didalam pembangunan Sistem Pakar terdapat arsitektur yang berisi komponen yang saling terintegrasi satu sama lainnya untuk memperoleh hasil dan tujuan yang telah ditetapkan dalam pembangunan sistem yang mampu menyelesaikan permasalahan yang ada. Berikut merupakan gambaran dari arsitektur Sistem Pakar[22].

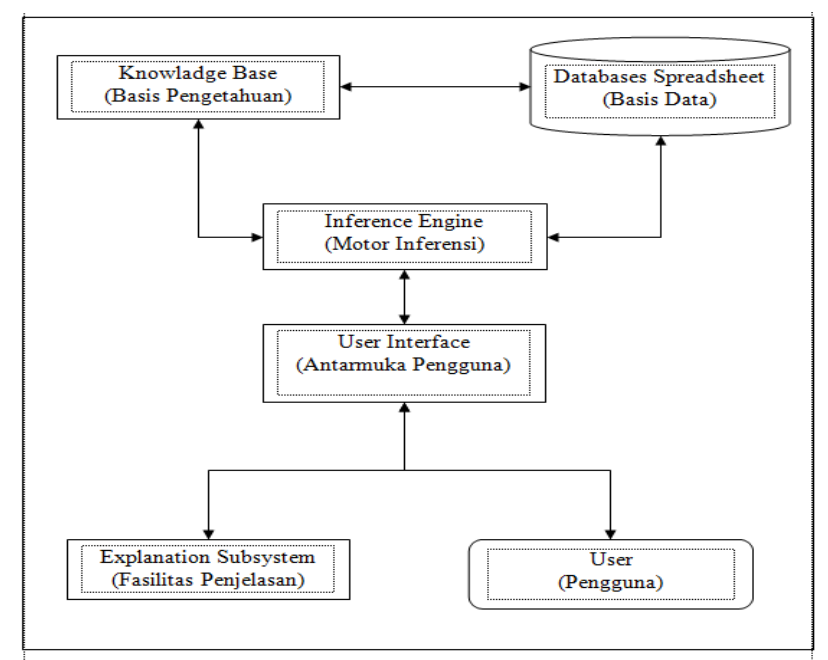

Gambar 1.Arsitektur Sistem Pakar

Berdasarkan gambar diatas, maka dapat dijelaskan bagianbagian yang merupakan komponen dasar dari Sistem Pakar diantaranya Knowladge Base,Databases Spreadsheet, Inference, Interface, Explanation, dan User. Berikut penjelasan dari gambar tersebut :

\section{Knowladge Base}

Merupakan istilah yang digunakan untuk pengumpulan datadata maupun informasi yang berkaitan dengan pengetahuan dari kepakaran. Knowladge Base sendiri memiliki 2 komponen yang saling berhubungan antara satu dengan lainnya[23], yang meliputi :

1. Fakta, merupakan hasil dari pengamatan atau identifikasi sebuah kasus yang memiliki nilai kebenaran yang valid atau sudah teruji, misalnya permasalahan, situasi ataupun kondisi terkini.

2. Aturan, merupakan alat yang digunakan dalam menentukan hasil atau tujuan yang akan dicapai berdasarkan kondisikondisi yang terjadi pada suatu kasus.

\section{Databases Spreadsheet}

Adalah wadah yang digunakan untuk menampung nilai-nilai data-data yang ada untuk dapat diproses dan dioleh menjadi infomasi yang bernilai kedalam komputer atau sistem cerdas, yang terdiri dari field, tabel pengetahuan, record atau isi dari informasi yang telah diketemukan[24].

\section{Inference}

Adalah sebuah teknik yang digunakan dalam melakukan pencarian atau pelacakan suatu tujuan berdasarkan aturan-aturan yang telah ditetapkan[25], selain itu mesin inferensi juga berfungsi sebagai alat yang mengatur dan pengendalian sebuah keputusan dengan berpedoman pada basis pengetahuan yang ada. Dalam cara pengimplementasiannya, mesin inferensi dibagi menjadi 3 bagian, diantaranya adalah sebagai berikut :

1. Forward Chaining, adalah teknik pencarian kasus dengan menggunakan teknik runut maju, hal ini diistilahkan dengan mencari kondisi-kondisi yang ada untuk dapat dirumuskan suatu hal atau kesimpulan.

2. Backward Chaining, adalah teknik pelacakan kasus dengan menggunakan teknik runut mundur, teknik ini menggunakan penalaran mundur kebelakang dengan terlebih dahulu mengumpulkan hipotesa yang kemudian akan ditelusuri hingga nantinya dapat menemukan hasil fakta-fakta penyebab hipotesa tersebut terjadi.

3. Kombinasi, adalah sebuah teknik gabungan antara Forward Chaining dengan Backward Chaining, hal ini dapat 
dilakukan jika terdapat suatu kasus yang memiliki permasalahan kompleks dan akan disimpulkan berdasarkan kondisi dan hipotesa yang banyak dan tersebar.

Berikut merupakan gambaran tentang teknik pencarian dengan menggunakan mesin inferensi :

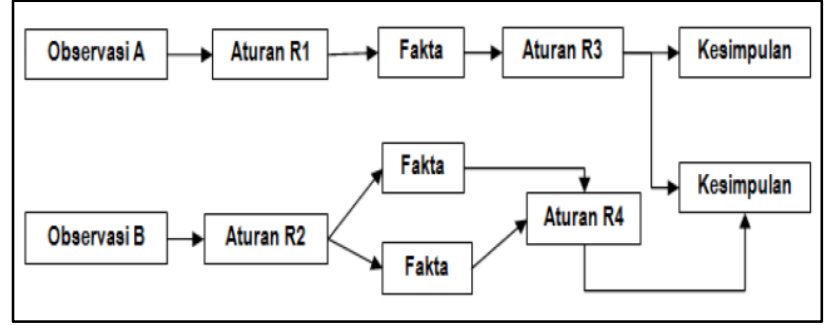

Gambar 2. Proses Inferensi

\section{Interface}

Adalah sebuah fasilitas yang digunakan untuk memberikan kemudahan bagi para pengguna dalam menjalankan atau mengoperasikan layanan atau aplikasi yang telah dirancang. Sebaiknya dalam membangun bagian-bagian interfacetetap memiliki pedoman bahwa Sistem Pakar memiliki dua layanan interface yaitu tampilan pengguna dan tampilan administrator atau pakar, hal ini dilakukan guna memberikan batasan hal-hal apa saja yang menjadi akses bagi siapapun yang menggunakan sistem ini. Tampilan pengguna digunakan untuk para pengunjung aplikasi layanan yang telah dibangun untuk menikmati fasilitas yang telah disediakan, sementara itu tampilan kepakaran merupakan tampilan yang dipergunakan dalam mengelola aturan dan pengetahuan sehingga sistem dapat berjalan dengan baik.

\section{Explanation}

Adalah sebuah fasilitas yang berfungsi sebagai penjelasan dari sistem yang telah dibuat, hal ini bertujuan untuk memberikan pengetahuan dan informasi kepada para pengguna tentang sistem ataupun layanan yang disediakan meliputi seluruh aspek pengetahuan dan layanan pada sistem.

\subsubsection{User}

Adalah orang yang menggunakan sistem ini, baik itu pengguna awam atau bahkan para pakar. Pengguna yang dirinya sebagai non experthanya dapat mempergunakan sistem untuk melakukan konsultasi, sedangkan para pakar menggunakan sistem agar menjadikan sebuah hasil yang ada pada sistem untuk dapat dianalisa sebagai bahan perbandingan tujuan atau kesimpulan.

\section{K-Nearest Neighbor}

Dalam[26] dijelaskan bahwa K-Nearest Neighbor merupakan metode yang menghasilkan kesimpulan dan penyelesaian masalah dengan melakukan pendekatan terhadap kasus sebelumnya, sehingga nantinya akan menghasilkan kesimpulan yang sesuai dengan kasus sebelumnya berdasarkan tinggkat kemiripan daftar sebab yang dialami oleh kasus baru. Berikut persamaan fungsi dari $K$-Nearest Neighbor:

$$
\operatorname{similarity}(T, S)=\frac{\left.\sum_{i=1}^{n} f\left(T_{1}, S_{1}\right) * W_{1}\right)}{W_{1}}
$$

Pada umumnya K-Nearest Neighbor digunakan pada kasus yang memiliki pola kemiripan pada kasus sebulumnya, di dunia kesehatan penggunaan $K$-Nearest Neighbor juga digunakan dalam menentukan diagnosa terhadap pasien yang analisa gejala-gejalanya diperoleh pada kasus-kasus diagnosa sebelumnya yang berguna untuk memastikan keakuratan terhadap pendiagnosaan yang telah dilakukan.

\section{Abcessus}

Penyakit ini muncul akibat penyebaran bakteri yang mengakibatkan peradangan pada jaringan sel kulit, hal ini terjadi disebabkan faktor lingkungan yang tidak bersih serta faktor kebersihan pada diri sendiri[27]. Bakteri penyebab penyakit ini adalah staphylococcus aureus yang merupakan bakteri dengan kemampuan penyebaran toksin pada jaringan sel kulit yang menyebabkan timbulnya pembengkakan serta mengakibatkan aliran sel darah putih meningkat pada bagian yang terkena infeksi, kondisi seperti ini akan menyebabkan keluarnya darah bercampur nanah pada jaringan sel kulit yang diserang staphylococcus aureus. Abcessus pada umumnya ini memiliki 2 jenis penyakit, yaitu : Furunkel dan Karbunkel[28].

\section{Abcessus Furunkel}

Penyakit Abcessus Furunkel merupakan jenis Abcessus yang disebabkan oleh ketidakmampuannya sistem pertahanan tubuh yang diserang oleh bakteri stafilokokus yang juga menyebabkan pelemahan pada kondisi tubuh seseorang[28]. Gejala-gejala klinis yang biasanya dialami oleh pasien yang terserang oleh Abcessus Furunkel meliputi : pembengkakan, demam, nyeri pada bagian kulit bengkak, terbentuk titik putih di benjolan, dan melepuh.

\section{Abcessus Karbunkel}

UntukAbcessus Karbunkel merupakan jenis Abcessus yang sering terjadi pada orang yang mengidap penyakit diabetes dan gangguan sistem imun, hal ini nantinya dapat berakibat munculnya titik-titik yang menyebar di bagian jaringan sel kulit[28]. Gejala-gejala klinis yang pada umumnya dialami oleh pasien yang terserang oleh jenis penyakit Abcessus Karbunkel meliputi : berair dan nanah, tersebar dibeberapa bagian kulit, terus membesar, kulit terasa hangat dan kaku.

\section{HASIL DAN PEMBAHASAN}

Reserch and Development merupakan metode penelitian yang akan digunakan dalam penelitian ini, hal ini dikarenakan hasil dari penelitian ini nantinya akan menghasilkan sebuah sistem yang mampu untuk memberikan pengetahuan tentang penyakit Abcessus dengan melakukan analisa pendiagnosaan menggunakan metode K-Nearest Neighbor.

Penelitian ini juga berorentasi pada pembangunan sebuah produk layanan diagnosa yang digunakan untuk melakukan pengidentifikasian terhadap penyakit Abcessus dengan menggunakan $K$-Nearest Neighbor, sehingga teknik penelitian yang baik dan sesuai digunakan adalah teknik kuantitatif, yaitu suatu teknik yang digunakan untuk memperoleh nilai kemungkinan diagnosa dengan terlebih dahulu melakukan perhitungan dan penerapan dengan metode yang digunakan.

Disamping itu pula dalam membangun sebuah sistem pendiagnosaan dengan menggunakan penerapan metode $K$ Nearest Neighbor dalam pendeteksian penyakit Abcessus perlu menyusun kerangka)kerja atau langkah-langkah yang akan dilakukan untuk dapat menghasilkan sistem yang diinginkan, didalam kerangka kerja yang disusun terdapat tahapan-tahapan yang meliputi : basis pengetahuan, penerapan K-Nearest Neighbor dan pengimplementasian sistem. Berikut gambaran dari kerangka kerja yang akan dilakukan : 


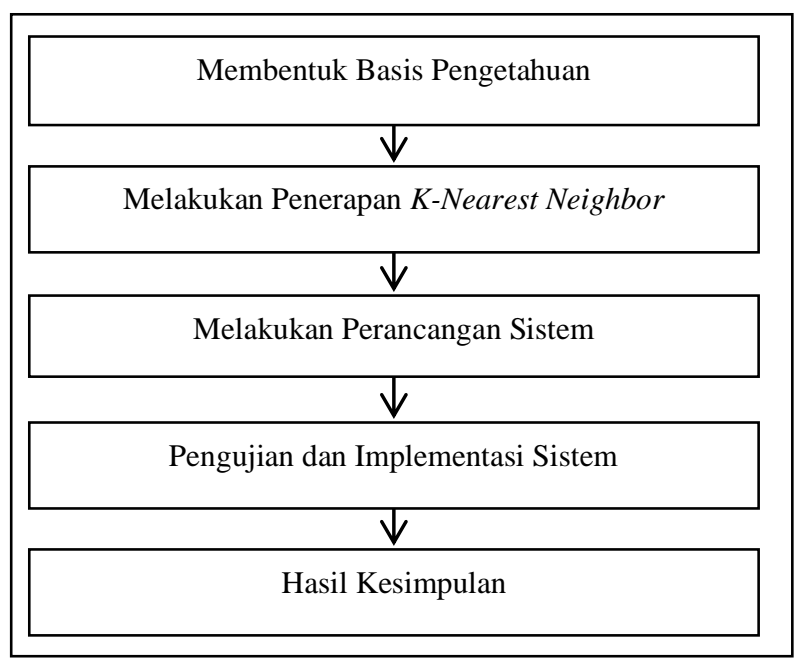

Gambar 3. Kerangka Kerja

\section{Basis Pengetahuan}

Perancangan Sistem Pakar dalam pediagnosaan Abcessus dibutuhkan penanaman pengetahuan yang berkaitan dengan Abcessus beserta gejala-gejala yang sering muncul pada pasien yang pernah teridentifikasi penyakit Abcessus sehingga nantinya pengetahuan tersebut akan diolah menjadi sebuah hasil solusi diagnosa yang dapat membantu para masyarakat dalam menaggulangi dan mengantisipasi Abcessus serta membantu dalam penekanan penyebaran penyakit tersebut. Berikut merupakan basis pengetahuan terkait penyakit Abcessus beserta gejela klinis yang terjadi.

Tabel 1. Data Pengetahuan

\begin{tabular}{|c|c|c|c|c|}
\hline \multirow[b]{2}{*}{ No } & \multirow{2}{*}{$\begin{array}{l}\text { Kode } \\
\text { Gejala }\end{array}$} & \multirow[b]{2}{*}{ Daftar Gejala } & \multicolumn{2}{|c|}{ Nilai Bobot } \\
\hline & & & $\begin{array}{c}\text { Furun } \\
\text { kel }\end{array}$ & $\begin{array}{c}\text { Karbu } \\
\text { nkel }\end{array}$ \\
\hline 1 & K01 & Pembengkakan & 0,6 & 0,6 \\
\hline 2 & K02 & Demam & 0,2 & \\
\hline 3 & K03 & $\begin{array}{l}\text { Nyeri pada bagian } \\
\text { kulit bengkak }\end{array}$ & 0,6 & \\
\hline 4 & K04 & $\begin{array}{l}\text { Terbentuk titik } \\
\text { putih di benjolan }\end{array}$ & 0,4 & \\
\hline 5 & K05 & Berair dan nanah & & 0,6 \\
\hline 6 & K06 & $\begin{array}{l}\text { Tersebar dibeberapa } \\
\text { bagian kulit }\end{array}$ & & 0,4 \\
\hline 7 & K07 & Terus membesar & & 0,4 \\
\hline 8 & K08 & Kulit terasa hangat & & 0,2 \\
\hline 9 & K09 & Melepuh & 0,4 & \\
\hline 10 & K10 & Kaku & & 0,2 \\
\hline 11 & K11 & Gatal & 0,3 & \\
\hline 12 & K12 & Kulit Memerah & 0,2 & \\
\hline 13 & K13 & Lecet dan Perih & & 0,4 \\
\hline
\end{tabular}

Berdasarkan data pengetahuan yang dipaparkan, maka untuk selanjutnya akan dilakukan penerapan metode K-Nearest
Neighbor yang digunakan untuk melakukan pencocokan dan mencari nilai kesamaan terhadap kasus yang telah ada sebelumnya, berikut beberapa kasus yang pernah terjadi tentang identifikasi penyakit Abcessus :

Tabel 2. Data Riwayat Kasus

\begin{tabular}{|c|c|c|c|}
\hline No & $\begin{array}{c}\text { Kode } \\
\text { Diagnosa }\end{array}$ & Gejala Dialami & Diagnosa \\
\hline 1 & D016 & \begin{tabular}{l}
\multicolumn{2}{l}{ Pembengkakan } \\
$($ K01), Demam \\
$($ K02), Nyeri pada \\
bagian \\
bengkak kulit \\
Terbentuk $r$ titik \\
putih di benjolan \\
$($ K04)
\end{tabular} & Furunkel \\
\hline 2 & D022 & $\begin{array}{lr}\text { Berair dan } & \text { nanah } \\
\text { (K05), Tersebar } & \text { dibeberapa bagian } \\
\text { kulit } & \text { (K06), } \\
\text { Pembengkakan } \\
\text { (K01) }\end{array}$ & Karbunkel \\
\hline 3 & D031 & $\begin{array}{ll}\text { Melepuh } & \text { (K09), } \\
\text { Kaku (K10) }\end{array}$ & Furunkel \\
\hline 4 & D042 & $\begin{array}{l}\text { Demam (K02), } \\
\text { Melepuh (K09) }\end{array}$ & Furunkel \\
\hline 5 & D067 & $\begin{array}{l}\text { Kaku } \quad(\mathrm{K} 10), \\
\text { Bengkak }(\mathrm{K} 01)\end{array}$ & Karbunkel \\
\hline 6 & D051 & $\begin{array}{l}\text { Pembengkakan } \\
(\mathrm{K} 01), \quad \text { Kulit } \\
\text { Memerah (K12) }\end{array}$ & Furunkel \\
\hline 7 & D081 & $\begin{array}{l}\text { Berair (K05), Kaku } \\
\text { (K10) }\end{array}$ & Karbunkel \\
\hline 8 & D075 & $\begin{array}{l}\text { Terus membesar } \\
\text { (K07), Kulit terasa } \\
\text { hangat (K02) }\end{array}$ & Karbunkel \\
\hline 9 & D091 & $\begin{array}{l}\text { Gatal (K11), Kulit } \\
\text { Memerah (K12) }\end{array}$ & Furunkel \\
\hline
\end{tabular}

\section{Penerapan K-Nearest Neighbor}

Pada tahapan ini akan dilakukan penerapan analisa K-Nearest Neighbor dalam melakukan proses pencarian similarity terhadap kondisi sebelumnya dengan kondisi yang baru akan didiagnosa, berikut kasus baru yang akan dilakukan pendiagnosaan :

Tabel 3. Kasus Baru

\begin{tabular}{ccccc}
\hline No & Kode & \multicolumn{2}{c}{ Gejala Dialami } & Diagnosa \\
\hline 1 & D099 & $\begin{array}{l}\text { Pembengkakan } \\
\text { Demam(K02), } \\
\text { pada bagian } \\
\text { bengkak (K03) }\end{array}$ & $\begin{array}{rll}\text { Nyeri } \\
\text { kulit }\end{array}$ & $? ? ?$ \\
\hline
\end{tabular}

Penyelesaian :

Langkah Ke-1 : Menentukan Nilai Bobot Kondisi :

Tabel 4. Nilai Kondisi

\begin{tabular}{|c|c|c|c|c|}
\hline No & \multicolumn{3}{|c|}{ Kondisi } & Nilai \\
\hline 1 & $\begin{array}{l}\text { Kondisi Lama } \\
\text { Kondisi Baru }\end{array}$ & Sama & Dengan & 1 \\
\hline 2 & $\begin{array}{l}\text { Kondisi Lama Ti } \\
\text { Kondisi Baru }\end{array}$ & ak San & Dengan & 0 \\
\hline
\end{tabular}

Langkah Ke-2 : Mencari nilai kondisi dengan menghubungkan kasus yang lama dengan kasus yang baru 
1. Nilai Kondisi dari persamaan D016 dengan D099

Tabel 5. Nilai D016 dengan D099

\begin{tabular}{|c|c|c|c|c|}
\hline Kode & K01 & K02 & K03 & K04 \\
\hline D016 & Ya & Ya & Ya & Ya \\
\hline D099 & Ya & Ya & Ya & Tidak \\
\hline Nilai Kondisi & 1 & 1 & 1 & 0 \\
\hline
\end{tabular}

2. Nilai Kondisi dari persamaan D022 dengan D099

Tabel 6. Nilai D022 dengan D099

\begin{tabular}{|c|c|c|c|}
\hline Kode & K05 & K06 & K071 \\
\hline D022 & Ya & Ya & Ya \\
\hline D099 & Tidak & Tidak & Ya \\
\hline Nilai Kondisi & 0 & 0 & 1 \\
\hline
\end{tabular}

3. Nilai Kondisi dari persamaan D031 dengan D099

Tabel 7. Nilai D031 dengan D099

\begin{tabular}{|c|c|c|}
\hline Kode & K09 & K10 \\
\hline D031 & Ya & Ya \\
\hline D099 & Tidak & Tidak \\
\hline Nilai Kondisi & 0 & 0 \\
\hline
\end{tabular}

4. Nilai Kondisi dari persamaan D042 dengan D099

Tabel 8. Nilai D042 dengan D099

\begin{tabular}{|c|c|c|}
\hline Kode & K02 & K09 \\
\hline D042 & Ya & Ya \\
\hline D099 & Ya & Tidak \\
\hline Nilai Kondisi & 1 & 0 \\
\hline
\end{tabular}

5. Nilai Kondisi dari persamaan D067 dengan D099

Tabel 9. Nilai D067 dengan D099

\begin{tabular}{|c|c|c|}
\hline Kode & K10 & K01 \\
\hline D067 & Ya & Ya \\
\hline D099 & Tidak & Ya \\
\hline Nilai Kondisi & 0 & 1 \\
\hline
\end{tabular}

6. Nilai Kondisi dari persamaan D051 dengan D099

Tabel 10. Nilai D051 dengan D099

\begin{tabular}{|c|c|c|}
\hline Kode & K01 & K12 \\
\hline D051 & Ya & Ya \\
\hline D099 & Ya & Tidak \\
\hline Nilai Kondisi & 1 & 0 \\
\hline
\end{tabular}

7. Nilai Kondisi dari persamaan D081 dengan D099

Tabel 11. Nilai D081 dengan D099

\begin{tabular}{|c|c|c|}
\hline Kode & K05 & K10 \\
\hline D081 & Ya & Ya \\
\hline D099 & Tidak & Tidak \\
\hline Nilai Kondisi & 0 & 0 \\
\hline
\end{tabular}

8. Nilai Kondisi dari persamaan D075 dengan D099
Tabel 12. Nilai D075 dengan D099

\begin{tabular}{|c|c|c|}
\hline Kode & K07 & K02 \\
\hline D075 & Ya & Ya \\
\hline D099 & Tidak & Ya \\
\hline Nilai Kondisi & 0 & 1 \\
\hline
\end{tabular}

9. Nilai Kondisi dari persamaan D091 dengan D099

Tabel 13. Nilai D091 dengan D099

\begin{tabular}{|c|c|c|}
\hline Kode & K11 & K12 \\
\hline D091 & Ya & Ya \\
\hline D099 & Tidak & Tidak \\
\hline Nilai Kondisi & 0 & 0 \\
\hline
\end{tabular}

Langkah Ke-3 : Menghitung nilai kedekatan kasus baru terhadap kasus-kasus sebelumnya:

$$
N D=\frac{\sum\left(\text { Nilai }_{-} \text {Kondisi }^{*} \text { NIilai }_{-} \text {Bobot }\right)}{\text { Total_Nilai_Bobot }}
$$

1. Kasus D016 dengan Kasus D099 :

$$
K 1=\frac{(1 * 0,6)+(1 * 0,2)+(1 * 0,6)+(0 * 0,4)}{0,6+0,2+0,6+0,4}=0,78
$$

2. Kasus D022 dengan Kasus D099:

$$
K 2=\frac{(0 * 0,6)+(0 * 0,4)+(1 * 0,4)}{0,6+0,4+0,4}=0,28
$$

3. Kasus D031 dengan Kasus D099:

$$
K 3=\frac{(0 * 0,4)+(0 * 0,4)}{0,4+0,4}=0
$$

4. Kasus D042 dengan Kasus D099:

$$
K 4=\frac{(0 * 0,2)+(0 * 0,6)}{0,2+0,6}=0,25
$$

5. Kasus D067 dengan Kasus D099 :

$$
K 5=\frac{(0 * 0,2)+(1 * 0,6)}{0,2+0,6}=0,75
$$

6. Kasus D051 dengan Kasus D099 :

$$
K 6=\frac{(1 * 0,6)+(0 * 0,2)}{0,6+0,2}=0,75
$$

7. Kasus D031 dengan Kasus D099 :

$$
K 7=\frac{(0 * 0,6)+(1 * 0,6)}{0,6+0,6}=0,5
$$

8. Kasus D075 dengan Kasus D099 :

$$
K 8=\frac{(0 * 0,4)+(1 * 0,2)}{0,4+0,2}=0,33
$$

9. Kasus D091 dengan Kasus D099 :

$$
K 8=\frac{(0 * 0,3)+(0 * 0,3)}{0,3+0,3}=0
$$

Langkah Ke-4 : Mencari nilai kedekatan yang paling tinggi :

$$
\begin{aligned}
& \operatorname{Max}_{(K 1 \ldots K 9)}=(0.78 ; 0.28 ; 0 ; 0.25 ; 0.75 ; 0.75 ; 0.5 ; 0.33 ; 0) \\
& =0.78
\end{aligned}
$$


Berdasarkan proses penerapan K-Nearest Neigbor yang telah dilakukan, maka dapat disimpulkan bahwa pasien tersebut kemungkinan mengalami Abcessus dengan nilai kedekatan terhadap kasus D016 yaitu 0,78.

\section{Perancangan Sistem}

Tahapan ini dilakukan untuk melakukan perancangan sistem yang akan dibangun meliputi perancangan basis data dan perancangan antarmuka layanan aplikasi, hal ini bertujuan untuk membangun sebuah sistem yang sesuai dengan kebutuhan dan disesuaikan dengan penggunaan yang telah dirancang. Dalam perancangan sistem yang dilakukan akan melibatkan prosesproses pembentukan tabel, gambaran halaman serta penjelasan dari setiap sesuatu yang dirancang. Berikut merupakan gambaran dari perancangan sistem yang akan dibangun.

\subsubsection{Perancangan Basis Data}

Basis data digunakan untuk dapat melihat tabel atau field yang digunakan dalam memenuhi kebutuhan sebuah sistem. Berikut rancangan basis data pada perancangan aplikasi Sistem Pakar untuk mendiagnosa Abcessus dengan mengadopsi penerapan analisa metode $K$-Nearest Neighbor :

\section{Tabel Pasien}

Tabel ini digunakan untuk menampung data identitas dari pasien yang akan melakukan pendiagnosaan atau menggunakan aplikasi layanan Sistem Pakar untuk mendiagnosa Abcessus dengan mengadopsi penerapan analisa metode K-Nearest Neighbor. berikut merupakan bentuk rancangan dari tabel data pasien :

Tabel 8. Tabel Pasien

\begin{tabular}{|c|l|c|c|l|}
\hline No & \multicolumn{1}{|c|}{$\begin{array}{c}\text { Nama } \\
\text { Field }\end{array}$} & $\begin{array}{c}\text { Jenis } \\
\text { Field }\end{array}$ & $\begin{array}{c}\text { Ukuran } \\
\text { Field }\end{array}$ & Keterangan \\
\hline 1 & Nopasien & Varchar & 5 & $\begin{array}{l}\text { Field ini untuk } \\
\text { menampung } \\
\text { nomor pasien }\end{array}$ \\
\hline 2 & Namapasien & Varchar & 50 & $\begin{array}{l}\text { Field ini untuk } \\
\text { menampung } \\
\text { nama pasien }\end{array}$ \\
\hline 3 & Usia & Integer & 4 & $\begin{array}{l}\text { Field ini untuk } \\
\text { menampung } \\
\text { usia pasien }\end{array}$ \\
\hline 4 & Alamat & Varchar & 100 & $\begin{array}{l}\text { Field ini untuk } \\
\text { menampung } \\
\text { alamat pasien }\end{array}$ \\
\hline
\end{tabular}

\section{Tabel Penyakit}

Tabel ini digunakan untuk menampung data-data ataupun informasi yang berkaitan dengan penyakit Abcessus yang nantinya dapat diolah atau digunakan dalam penambahan data atau perubahan data yang terbaru. berikut merupakan bentuk rancangan dari tabel data penyakit :

Tabel 9. Tabel Penyakit

\begin{tabular}{|c|c|c|c|c|}
\hline No & $\begin{array}{c}\text { Nama } \\
\text { Field }\end{array}$ & $\begin{array}{c}\text { Jenis } \\
\text { Field }\end{array}$ & $\begin{array}{c}\text { Ukuran } \\
\text { Field }\end{array}$ & Keterangan \\
\hline 1 & $\begin{array}{l}\text { Kodepenya } \\
\text { kit }\end{array}$ & Varchar & 10 & $\begin{array}{l}\text { Field ini untuk } \\
\text { menampung } \\
\text { kode penyakit }\end{array}$ \\
\hline
\end{tabular}

Tabel 9. Tabel Penyakit Lanjutan

\begin{tabular}{|c|c|c|c|c|}
\hline No & $\begin{array}{c}\text { Nama } \\
\text { Field }\end{array}$ & $\begin{array}{c}\text { Jenis } \\
\text { Field }\end{array}$ & $\begin{array}{c}\text { Ukuran } \\
\text { Field }\end{array}$ & Keterangan \\
\hline 2 & $\begin{array}{l}\text { Namapenya } \\
\text { kit }\end{array}$ & Varchar & 50 & $\begin{array}{l}\text { Field ini untuk } \\
\text { menampung } \\
\text { nama penyakit }\end{array}$ \\
\hline
\end{tabular}

3. Tabel Gejala

Tabel ini digunakan untuk menampung data-data ataupun informasi yang berkaitan dengan gejala-gejala klinis yang terdapat pada penyakit Abcessus yang nantinya dapat diolah atau digunakan dalam penambahan data atau perubahan data yang terbaru. berikut merupakan bentuk rancangan dari tabel data gejala yang dirancang :

Tabel 10. Tabel Gejala

\begin{tabular}{|c|l|c|c|l|}
\hline No & $\begin{array}{c}\text { Nama } \\
\text { Field }\end{array}$ & $\begin{array}{c}\text { Jenis } \\
\text { Field }\end{array}$ & $\begin{array}{c}\text { Ukuran } \\
\text { Field }\end{array}$ & Keterangan \\
\hline 1 & Kode gejala & Varchar & 10 & $\begin{array}{l}\text { Field ini untuk } \\
\text { menampung } \\
\text { kode gejala }\end{array}$ \\
\hline 2 & $\begin{array}{l}\text { Nama } \\
\text { gejala }\end{array}$ & Varchar & 50 & $\begin{array}{l}\text { Field ini untuk } \\
\text { menampung } \\
\text { nama gejala }\end{array}$ \\
\hline
\end{tabular}

4. Tabel Basis Pengetahuan

Tabel ini digunakan untuk menampung sinkronisasi atauran yang dibentuk dengan menyesuaikan data gejala dengan data penyakit Abcessusi beserta nilai yang diperoleh dari pakar. yang nantinya dapat diolah atau digunakan dalam pembentukan basis pengetahuan yang terbaru. berikut merupakan bentuk rancangan dari tabel data basis pengetahuan yang dirancang :

Tabel 11. Tabel Basis Pengetahuan

\begin{tabular}{|c|l|l|c|l|}
\hline No & $\begin{array}{c}\text { Nama } \\
\text { Field }\end{array}$ & $\begin{array}{c}\text { Jenis } \\
\text { Field }\end{array}$ & $\begin{array}{c}\text { Ukuran } \\
\text { Field }\end{array}$ & Keterangan \\
\hline 1 & $\begin{array}{l}\text { Kodepe } \\
\text { nyakit }\end{array}$ & Varchar & 10 & $\begin{array}{l}\text { Field ini untuk } \\
\text { menampung } \\
\text { kode penyakit }\end{array}$ \\
\hline 2 & $\begin{array}{l}\text { Kodege } \\
\text { jala }\end{array}$ & Varchar & 10 & $\begin{array}{l}\text { Field ini untuk } \\
\text { menampung } \\
\text { kode gejala }\end{array}$ \\
\hline 3 & Bobot & Double & - & $\begin{array}{l}\text { Field ini untuk } \\
\text { menampung } \\
\text { bobot }\end{array}$ \\
\hline
\end{tabular}

5. Tabel Diagnosa

Tabel ini digunakan untuk menampung hasil pendiagnosaan yang telah dilakukan oleh pasien, hal ini bertujuan untuk menyimpan riwayat penyakit pasien tersebut sehingga mempermudah dalam menindaklanjuti permasalahan diagnosa kedepan. Rancangan tabel ini meliputi nomor diagnosa pasien yang bersifat unik, selain itu terdapat nomor pasien yang disesuaikan dengan pertama sekali mendaftar, disamping itu terdapat nama pasien, hasil diagnosa berserta nilai kemungkinan yang telah dihitung dengan penerapan metode K-Nearest Neighbor dan tanggal diagnosa pada saat pasien melakukan konsultasi. Berikut merupakan bentuk rancangan dari tabel data diagnosa yang dirancang : 
Tabel 12. Tabel Diagnosa

\begin{tabular}{|c|c|c|c|c|}
\hline No & $\begin{array}{l}\text { Nama } \\
\text { Field }\end{array}$ & $\begin{array}{l}\text { Jenis } \\
\text { Field }\end{array}$ & $\begin{array}{c}\text { Ukur } \\
\text { an } \\
\text { Field }\end{array}$ & Keterangan \\
\hline 1 & $\begin{array}{l}\text { No } \\
\text { diagnosa }\end{array}$ & Varchar & 10 & $\begin{array}{lr}\text { Field } & \text { ini } \\
\text { digunakan untuk } \\
\text { menampung kode } \\
\text { diagnosa }\end{array}$ \\
\hline 2 & Nopasien & Varchar & 10 & $\begin{array}{lr}\text { Field } & \text { ini } \\
\text { digunakan untuk } \\
\text { menampung kode } \\
\text { pasien yang akan } \\
\text { didiagnosa }\end{array}$ \\
\hline 3 & $\begin{array}{l}\text { Namapasi } \\
\text { en }\end{array}$ & Varchar & 50 & $\begin{array}{l}\text { Field ini } \\
\text { digunakan untuk } \\
\text { menampung nama } \\
\text { pasien }\end{array}$ \\
\hline 4 & Hasilnilai & Double & - & $\begin{array}{lr}\text { Field } & \text { ini } \\
\text { digunakan untuk } \\
\text { menampung hasil } \\
\text { kepastian }\end{array}$ \\
\hline 5 & Diagnosa & Varchar & 50 & $\begin{array}{lr}\text { Field } & \text { ini } \\
\text { digunakan untuk } \\
\text { menampung hasil } \\
\text { diagnosa }\end{array}$ \\
\hline 6 & $\begin{array}{l}\text { Tanggal } \\
\text { diagnosa }\end{array}$ & $\begin{array}{c}\text { Date } / T i \\
\text { me }\end{array}$ & - & $\begin{array}{l}\text { Field ini } \\
\text { digunakan untuk } \\
\text { menampung } \\
\text { tanggal diagnosa }\end{array}$ \\
\hline
\end{tabular}

\section{Tabel Admin Pakar}

Tabel ini digunakan untuk menampung data yang berkaitan dengan admin, hal ini dilakukan untuk mengakses halaman kepakaran sehingga dapat mengelola data pengetahuan yang ada, adapun pengguna yang dapat masuk adalah pengguna yang didaftarkan sebagai admin pakar. Berikut merupakan bentuk rancangan dari tabel admin pakar yang dirancang :

\begin{tabular}{|c|c|c|c|c|}
\hline No & $\begin{array}{l}\text { Nama } \\
\text { Field }\end{array}$ & $\begin{array}{l}\text { Jenis } \\
\text { Field }\end{array}$ & $\begin{array}{c}\text { Ukuran } \\
\text { Field }\end{array}$ & Keterangan \\
\hline 1 & Username & Varchar & 10 & $\begin{array}{l}\text { Field ini untuk } \\
\text { menampung } \\
\text { username }\end{array}$ \\
\hline 2 & Password & Varchar & 10 & $\begin{array}{l}\text { Field ini untuk } \\
\text { menampung } \\
\text { password }\end{array}$ \\
\hline
\end{tabular}

\subsubsection{Perancangan Interface}

Tampilan halaman layanan diagnosa yang dirancang digunakan untuk menampilkan semua halaman yang nantinya dapat digunakan oleh pengguna dalam mengoperasikan dan mengelola data-data yang berkaitan dengan penyakit Absesccus dengan menerapkan K-Nearest Neighbor, berikut terdapat bentuk dari rancangan tampilan atau user interface dari aplikasi layanan diagnosa yang dibangun.

\section{Rancangan Halaman Utama}

Rancangan ini dibentuk dengan tujuan untuk dapat memberikan informasi-informasi layanan yang dapat digunakan sebagai pengguna layanan. Meliputi menu-menu layanan dan penjelasan dari layanan yang disediakan. Berikut tampilan dari rancangan halaman utama.

\begin{tabular}{||l||l||c||}
\hline \multicolumn{2}{|l|}{ Sistem Pakar Mendiagnosa Penyakit Abseccus } & \\
\hline \multicolumn{2}{|c|}{ Master Data } & \multicolumn{2}{|l|}{ Kepakaran } & Laporan \\
\hline Data Pasien & & Diagnosa Pakar \\
Tentang Pakar & & \\
\hline
\end{tabular}

Gambar 4. Rancangan Halaman Utama

\section{Rancangan Data Pasien}

Rancangan ini dibangun untuk menampung data diri pasien yang akan melakukan pendiagnosaan terhadap penyakit Absesccus dengan menerapkan K-Nearest Neighbor, hal ini bertujuan untuk pengolahan data pasien yang akan direkapitulasi dengan hasil diagosa pasien tersebut. Berikut tampilan dari rancangan data pasien.

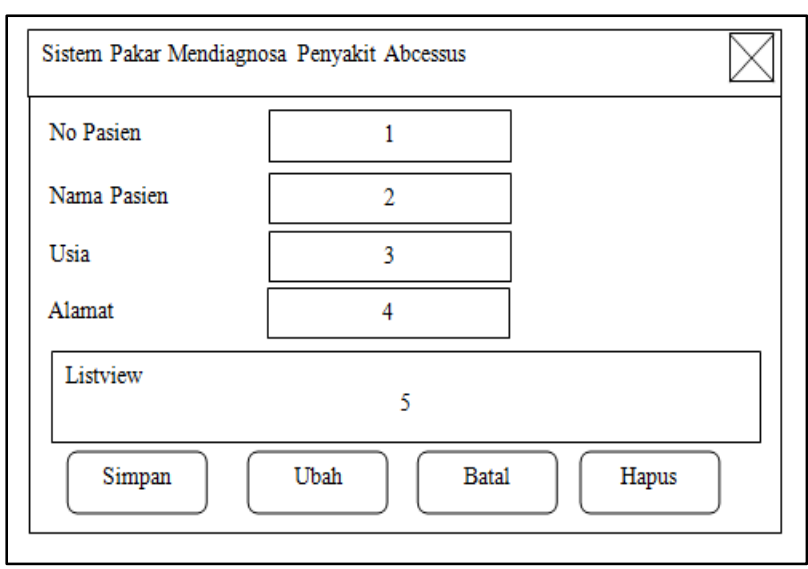

Gambar 5. Rancangan Data Pasien

3. Rancangan Data Diagnosa

Rancangan ini disediakan untuk menampilkan hasil diagnosa pasien terhadap penyakit Absesccus beserta nilai probabilitas penyakit tersebut dengan menggunakan $K$ Nearest Neighbor, selain itu tampilan ini ddapat dijadikan layanan rekap medis dari pasien yang telah melakukan diagnosa dengan sistem ini. Berikut tampilan dari rancangan data diagnosa.

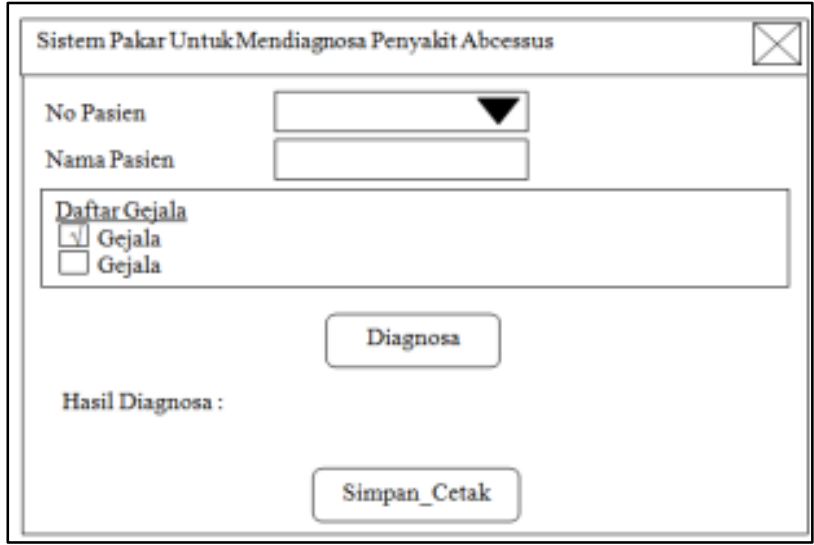

Gambar 6. Rancangan Data Diagnosa 
4. Rancangan Data Pengetahuan

Rancangan ini disediakan untuk menampilkan dan mengelola data-data yang berisi informasi yang berkaitan dengan penegtahuan penyakit Absesccus beserta nilai probabilitas penyakit tersebut, hal ini dilakukan mengantisipasi perubahan data atau penambahan pengetahuan pada aplikasi layanan diagnosa yang akan dibangun. Berikut tampilan rancangan dari data pengetahuan:

\begin{tabular}{|c|c|c|c|}
\hline \multicolumn{4}{|c|}{ Sistem Pakar Untuk Mendiagnosa Penyakit Abscessus } \\
\hline \multicolumn{3}{|l|}{ Kode Gejala } & \\
\hline \multicolumn{3}{|l|}{ Nama Gejala } & \\
\hline \multicolumn{3}{|l|}{ Nama Penyakit } & \\
\hline \multicolumn{3}{|l|}{ Bobot Nilai } & \\
\hline \multicolumn{3}{|l|}{ Listview } & \\
\hline Simpan & Ubah & Batal & Hapus \\
\hline
\end{tabular}

Gambar 7. Rancangan Data Pengetahuan

\section{Penerapan Sistem}

Sistem Pakar ini diimplementasikan dalam sebuah sistem layanan diagnosa berbasis aplikasi sehingga dapat digunakan oleh masyarakat dalam mengidentifikasi penyakit Abcessus dengan mengadopsi penerapan analisa metode $K$-Nearest Neigbor yang berfungsi untuk menentukan nilai kemungkinan atau peluang terhadap pasien dengan membandingkan pada kasus yang ada sebelumnya. Dalam aplikasi layanan diagnosa Abcessus ini terdapat tampilan pengujian sistem yang meliputi : halaman utama, data pasien, dan halaman konsultasi. Berikut penjelasan dari pengujian sistem yang dilakukan:

\subsubsection{Halaman Utama}

Pada halaman ini berisi menu layanan aplikasi seperti data pasien, konsultasi, data gejala, data penyakit, info penyakit, info pakar dan admin pakar. Halaman ini akan muncul pertama kali pada saat aplikasi layanan pendiagnosaan Abcescus diaktifikan atau digunakan. Berikut tampilan dari halaman utama :

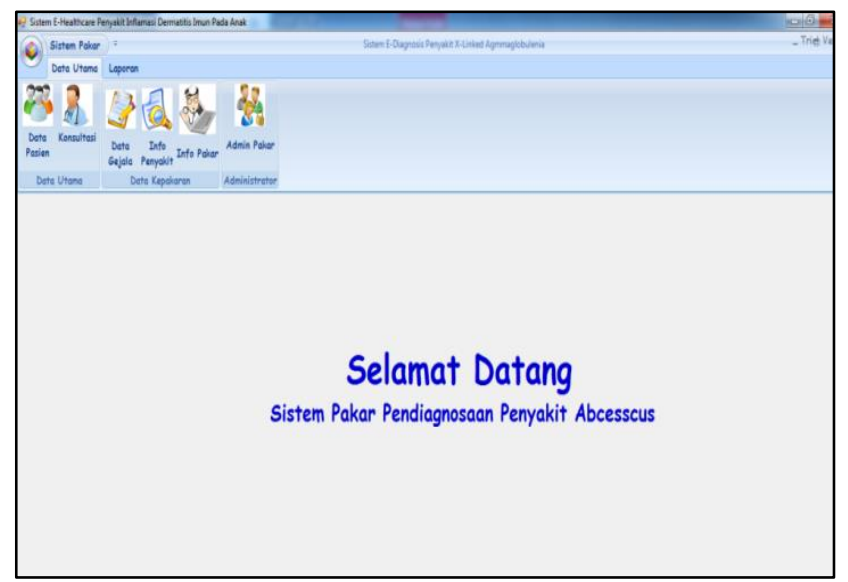

Gambar 8. Tampilan Halaman Utama

Pengguna dapat mengakses aplikasi layanan diagnosa ini dengan terlebih dahulu melakukan pendaftaran pada layanan aplikasi yang dibangun, sehingga pengguna yang dapat menggunakan aplikasi ini adalah para masyarakat yang telah melakukan pendaftaran.

172 Puji Sari Ramadhan

\section{Data Pasien}

Halaman ini merupakan halaman yang disediakan untuk para pengguna sebelum melakukan pendiagnosaan, hal ini bertujuan untuk menampung riwayat gejala atau rekapitulasi penyakit pasien sehingga nantinya dapat digunakan untuk merumuskan pendiagnosaan penyakit yang menyerang pasien kedepan. Dalam halaman ini terdapat beberapa identitas yang wajib diisi, meliputi : no, nama, usia dan alamat pasien yang akan melakukan diagnosa. Berikut ini merupakan tampilan data pasien yang dibangun :

\begin{tabular}{|c|c|c|c|}
\hline$\square$ Data Pasien & & & \begin{tabular}{|l|l|l|}
0 & 回 & $x$ \\
\end{tabular} \\
\hline \multicolumn{4}{|c|}{ Pengisian Data Pasien } \\
\hline & No Pasien & $P 005$ & \\
\hline & Nama Pasien & & \\
\hline & Usia & Tahun & \\
\hline & Alamat & & \\
\hline No Pasien & Nama Pasien & Usia & Alamat \\
\hline P001 & puji & 15 & medan \\
\hline $\mathrm{P} 002$ & puji & 13 & medan \\
\hline P003 & Hamdi & 13 & Medan \\
\hline $\mathrm{P} 004$ & Sari & 12 & medan \\
\hline \multicolumn{4}{|l|}{1} \\
\hline (C) Simpan & Ubah & S Batal & 8 Hapus \\
\hline
\end{tabular}

Gambar 9. Tampilan Data Pasien

Dalam hamalana ini jug disediakan layanan pengelolaan data pasien yang meliputi pengelolahan simpan data, hapus data, tampilkan data dan perubahan data. Hal ini dilakukan guna mengantisipasi perubahan data pada pasien atau masyarakat yang telah melakukan konsultasi.

\subsubsection{Layanan Pendiagnosaan}

Pada halaman diagnosa yang ditampilkan, merupakan halaman yang dipergunakan dalam melakukan pendiagnosaan Abscessus dengan terlebih dahulu memilih gejala-gejela yang ada dan langsung menekan tombol diagnosa sehingga nantinya akan muncl hasil diagnosa pasien dengan disertai nilai kepastian atau kemungkinan dari penyakit yang menyerang. Berikut merupakan tampilan layanan diagnosa :

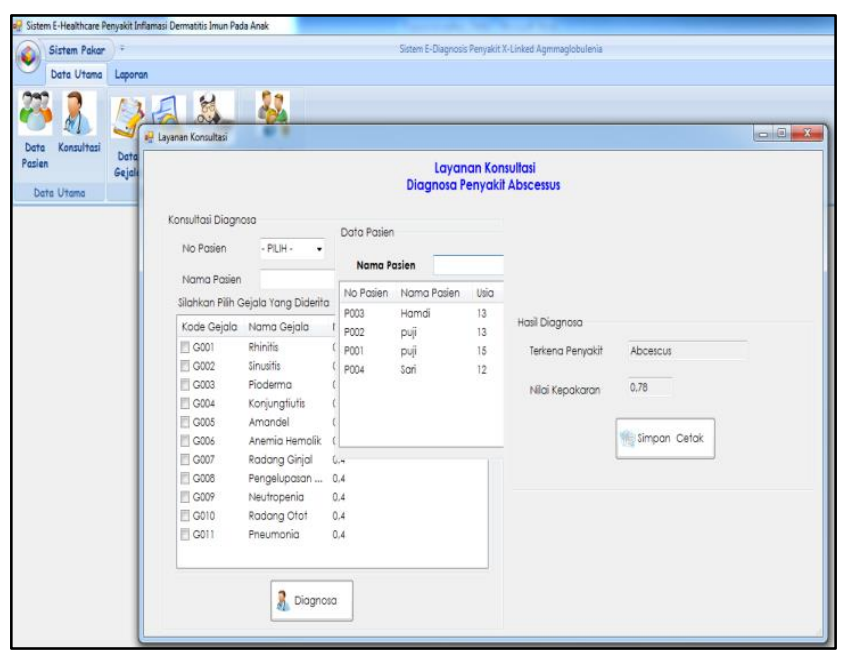

Gambar 10. Tampilan Konsultasi Diagnosa

Halaman ini dirancang dengan menanamkan pengetahuan tentang Abscessus yang kemudian dilakukan pencarian persamaan diagnosa atas gejala-gejala yang dialami pada kasus

DOI: https://doi.org/10.30743/infotekjar.v3i2.1003 
baru terhadap kasus-kasus yang terjadi terdahulu dengan menerapkan metode K-Nearest Neigbor.

\section{Halaman Pengetahuan}

Pada halaman pengetahuan akan ditampilkan beberapa layanan yang dapat digunakan untuk mengelola data baik informasi atau pengetahuan tentang penyakit Abscessus dan pembentukan aturan yang nantinya dapat digunakan dalam penentuan gejala terhadap penyakit beserta nilai kemungkinan dari penyakit tersebut,. Berikut merupakan tampilan halaman pengetahuan :

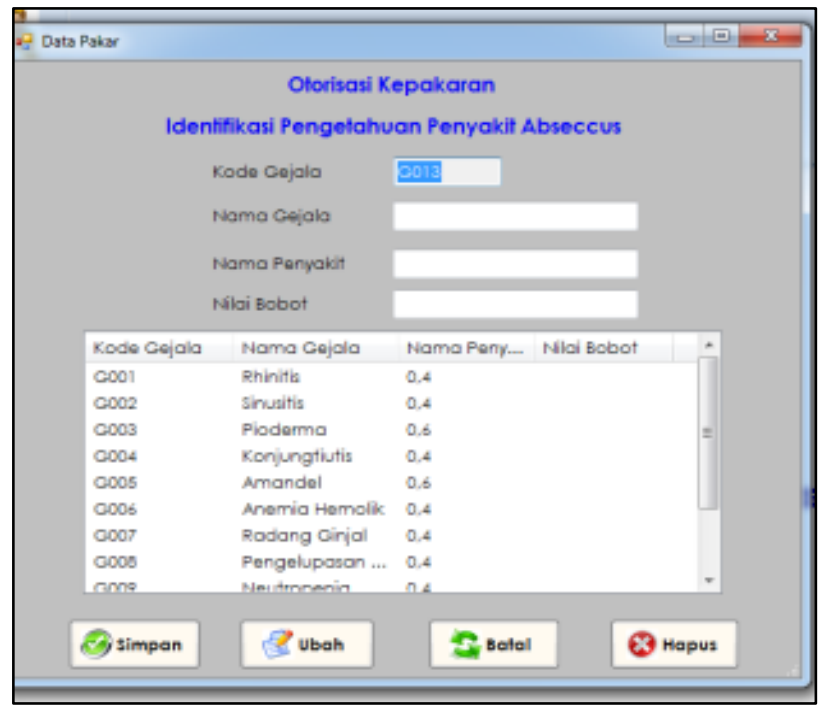

Gambar 10. Tampilan Konsultasi Diagnosa

Pada halaman pengetahuan tersedia fasilitas penyimpanan basis pengetahuan yang baru sehingga dapat ditambah sesuai dengan keadaan kedepan, selain itu terdapat perubahan data pengetahuan yang berfungsi untuk selalu memperbaruhi data pengetahuan serta penghapusan data pengetahuan yang digunakan untuk menghapus data pengetahuan yang tidak digunakan lagi.

\section{KESIMPULAN}

Berdasarkan penjelasan yang telah dikemukakan tentang pembangunan sistem layanan diagnosa Abscessus dengan menerapkan $K$-Nearest Neigbor maka dapat disimpulkan beberapa hal, diantaranya :

1. Sistem Pakar dalam pendiagnosaan Abscessusini merupakan kumpulan tahapan yang meliputi : pengumpulan data pengetahuan Abscessusdan pencarian persamaan diagnosa atas gejala-gejala yang dialami pada kasus baru terhadap kasus-kasus yang terjadi terdahulu dengan menerapkan metode $K$-Nearest Neighbor.

2. Layanan konsultasi ini dirancang menggunakan K-Nearest Neighbor dalam mencari hasil diagnosa Abscessus, sehingga layanan ini bisa dipergunakan sebagai aplikasi deteksi Abscessus yang dapat digunakan dalam pengambilan diagnosa oleh petugas kesehatan.

3. Sistem Pakar yang dirancang untuk mencari hasil diagnosa Abscessus dengan menggunakan K-Nearest Neighbor telah sesuai dengan kaidah dan rumusan yang terdapat pada algoritma dan penerapan metode yang digunakan, sehingga nantinya aplikasi ini dapat dan layak untuk digunakan untuk masyarakat luas.

\section{REFERENCES}

[1] S. Nurajizah and M. Saputra, "Sistem Pakar Berbasis Android Untuk Diagnosa Penyakit Kulit Kucing Dengan Metode Forward Chaining," J. Pilar Nusa Mandiri, vol. 14, no. 1, pp. 7-14, 2018.

[2] S. A. Putri and E. P. Saputra, "Perancangan Aplikasi Sistem Pakar Diagnosa Awal Kanker Reproduksi Wanita Dengan Metode Certainty Factor," vol. 2, no. 3, pp. 63-68, 2018.

[3] P. S. Ramadhan, "SISTEM PAKAR PENDIAGNOSAAN DERMATITIS IMUN MENGGUNAKAN TEOREMA BAYES," InfoTekJar(Jurnanl Nas. Inform. dan Teknol. Jaringan), vol. 3, no. 73, pp. 43-48, 2018.

[4] P. S. Ramadhan, "Sistem Pakar Pendeteksian Varicella Simplex Dengan Menggunakan Teorema Bayes," vol. 5, no. 5, pp. 454-459, 2018.

[5] Tuslaela and D. Permadi, "Sistem Pakar Diagnosa Penyakit Gigi Dan Mulut Berbasis Web dengan Metode Forward Chaining," J. PROSISKO, vol. 5, no. 1, pp. 17-26, 2018.

[6] S. Wulandari, Kadek and Made, "Prediction of Days in Hospital Dengue Fever Patients using K-Nearest Neighbor," vol. 3, no. 1, pp. 23-25, 2018.

[7] M. El Agha, A. Jarghon, and S. S. A. Naser, "Polymyalgia Rheumatic Expert System," no. August, 2017.

[8] M. S. Hossain, F. Ahmed, Fatema-Tuj-Johora, and K. Andersson, "A Belief Rule Based Expert System to Assess Tuberculosis under Uncertainty," J. Med. Syst., vol. 41, no. 3, 2017.

[9] Minarn, I. Warman, and W. Handayani, "Case-Based Reasoning (Cbr) Pada Sistem Pakar Identifikasi Hama Dan Penyakit Tanaman Singkong Dalam Usaha Meningkatkan Produktivitas Tanaman Pangan," $J$. TEKNOIF, vol. 5, no. 1, pp. 41-47, 2017.

[10] F. M. Hadini, "Detection System Milkfish Formalin Android-Based Method Based on Image Eye Using Naive Bayes Classifier," vol. 9, no. 1, pp. 2-5, 2017.

[11] A. Suyatno and D. M. Khairina, "PENDETEKSI GANGGUAN JARINGAN LOKAL MENGGUNAKAN METODE CERTAINTY FACTOR," vol. 13, no. 2, pp. 60-64, 2018.

[12] B. Sinaga, P. M. Hasugian, and A. M. Manurung, "Sistem Pakar Mendiagnosa Kerusakansmartphone," vol. 3, no. 1, 2018.

[13] A. Joshi and M. Ashish, "Analysis Of K-Nearest Neighbor Technique For Breast Cancer Disease Classification," Int. J. Recent Sci. Res., vol. 8, no. 8, pp. 1005-19008, 2017.

[14] M. Zuhaer and M. H. M. Alhabib, "Face Recognition System Based on Kernel Discriminant Analysis , KNearest Neighbor and Support Vector Machine," vol. 5, no. 3, pp. 335-338, 2018.

[15] Mohamad Hadi, M. Misdram, and R. F. A, "Perancangan Sistem Pakar Diagnosa Penyakit Ayam Dengan Metode Forward Chaining," JImp, vol. 2, no. no bagian volume, pp. 111-139, 2016.

[16] A. Al-Ajlan, "The Comparison between Forward and Backward Chaining," Int. J. Mach. Learn. Comput., vol. 5, no. 2, pp. 106-113, 2015.

[17] P. S. Ramadhan and Fatimah, "Sistem E-Healthcare Untuk Mendiagnosa Penyakit Inflamasi Dermatitis Imun Anak Dengan Menggunakan Metode Certainty Factor," vol. 1, no. 1, pp. 251-256, 2018.

[18] P. S. Ramadhan and U. Fatimah, "Analisis Perbandingan Metode ( Certainty Factor, Dempster Shafer dan Teorema Bayes ) untuk Mendiagnosa 
Penyakit Inflamasi Dermatitis Imun pada Anak," Saintikom, vol. 17, no. 2, pp. 151-157, 2018.

[19] S. Qwaider and S. S. A. Naser, "Expert System for Diagnosing Ankle Diseases," no. August, 2017.

[20] A. K. Verawaty , Mesran, Suginam, "Jambu Biji Menggunakan Metode Bayes," vol. 2, no. 1, pp. 78-81, 2017.

[21] U. Hanifah, F. T. Elektro, U. Telkom, A. V. Jones, and F. Chaining, "DETEKSI PENYAKIT PTERIGIUM MENGGUNAKAN FORWARD CHAINING DAN ALGORITMA VIOLA JONES DETECTION OF PTERIGIUM DISEASE USING FORWARD CHAINING AND VIOLA," vol. 5, no. 3, pp. 61186125, 2018.

[22] J. Divya and K. Sreekumar, "A Survey on Expert System in Agriculture," Int. J. Comput. Sci. Inf. Technol., vol. 5, no. 6, pp. 7861-7864, 2014.

[23] A. Jamal and Sukadi, "Rancang Bangun Sistem Pakar Diagnosa Kerusakan Notebook Pada Widodo Computer Ngadirojo kabupaten Pacitan," J. Speed Sentra Penelit. Eng. dan Edukasi -, vol. 7, no. 3, pp. 52-58, 2015.

[24] T. Wang, G. Zhang, J. Zhao, Z. He, Z. Wang, and M. J. Jiménez-Pérez, "Fault Diagnosis of Electric Power Systems Based on Fuzzy Reasoning Spiking Neural P Systems," IEEE Trans. Power Syst., vol. 30, no. 3, pp. 1182-1194, 2015.

[25] U. Siti Hawa, Abdullah, "Sistem Pakar Diagnosa Penyakit Pada Tanaman Kakao Menggunakan Metode Forward Chaining (Studi Kasus Dinas Perkebunan Indragiri Hilir) 1,” vol. 4, pp. 1-8, 2015.

[26] P. S. Ramadhan, Mengenal Metode Sistem Pakar, 1st ed. Medan: Penerbit Uwais, 2018.

[27] J. dan K. N. Akib, A. Roma, Penyakit Defisiensi Imun, 1st ed. Jakarta: Ikatan Dokter Indonesia, 2015.

[28] A. Maharani, Penyakit Kulit, 1st ed. Yogyakarta: Pustaka Baru Press, 2015.

\section{NOMENCLATURE}

Berikut Nomenklatur dari fungsi persamaan yang ada pada penelitian ini.
T,S artinya Nilai Kedekatan
W artinya Nilai Bobot

\section{BIODATA PENULIS}

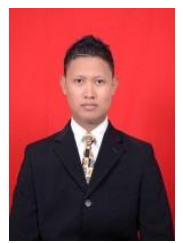

Puji Sari Ramadhan

Dosen tetap STMIK TRIGUNA DHARMA, yang mengampu mata kuliah kecerdasan buatan dan aplikasi pemograman web, mobile dan dekstop. 